\title{
Mapping the Rainbow of Review: Recognising Variable Intensity
}

\author{
DeAn R KNIGHT*
}

This article explores Professor Taggart's "rainbow of review", a metaphor which seeks to capture the different intensity applied by courts when reviewing the administrative decisions of public bodies, office-holders and officials. The primary purpose of this article is to demonstrate the widespread application of variable intensity in New Zealand administrative law, both in its overt and covert forms. This article also builds on the contextualism-deference couplet mentioned by Professor Taggart - the idea that a commitment to the importance of context must also involve the application of deference (or variability) in judicial supervision. The secondary purpose of the article is to examine the attitudes of local jurists, scholars and practitioners to the contextualism-variability couplet. A strong commitment to the first arm of the couplet is evident, but there are greatly varying attitudes to the latter arm. The article aims to build a foundation for the future examination of the ideal mechanism to capture and calibrate variable intensity.

\footnotetext{
*Senior Lecturer, Faculty of Law and Associate Director, New Zealand Centre for Public Law, Victoria University of Wellington. Thanks, subject to the usual caveat, to Graeme Austin, Eddie Clark, Claudia Geiringer, Geoff McLay, Tim Miller, Steven Price, Rayner Thwaites and Hanna Wilberg for valuable feedback on draft versions of this article and the topic generally. Thanks also to Conrad Reyners and Jonathan Glendenning for research and other assistance with this article.
} 


\section{Introduction}

It is an honour to contribute to this issue responding to Professor Taggart's last major work on proportionality, unreasonableness and deference. ${ }^{1}$ Professor Taggart — or Mike, as he was fondly known — truly was a rangatira (chief) of the intellectual community in both New Zealand and the common law world. Mike made an immense contribution to administrative law through his powerful, and always animated, scholarship. But Mike was also a very generous mentor for fledgling scholars such as me, always willing to provide cogent feedback, wise words and sage advice. I value the conversations and exchanges we had in the all too short period we were academic colleagues.

In reflecting on Professor Taggart's last work on this topic, I suspect others will be preoccupied by the banner headline: "Taggart endorses proportionality review". Given Taggart's pedigree as a proud common law scholar, the acceptance that a doctrine — or, rather, methodology born in the field of human rights jurisprudence should take its place on the rainbow of review of mainstream administrative law is of quite some significance. Of course, his endorsement of proportionality review is limited. He accepts - I sense, reluctantly — the bifurcation of administrative law. Proportionality review should only apply, he says, to "the 'rights' part of the review rainbow". ${ }^{2}$ By this he means cases "implicating directly human rights", both fundamental common law rights and those enumerated in statutory bills of rights. ${ }^{3}$ For the balance of the rainbow, that is, "public wrongs", the traditional formulation of Wednesbury unreasonableness ${ }^{4}$ should reign singularly. Proportionality is banished from situations where "a court is applying the grounds of administrative law to see if the [decisionmaker] has committed material legal error". ${ }^{5}$ So too, in Professor Taggart's view, there is no room for Wednesbury's offspring: variegated, intensified or "Cookeian" unreasonableness. ${ }^{6}$ The supremacy of the traditional conception of Wednesbury unreasonableness (the "longstop", "safety net" or "residual" kind) should be restored on this side of the rainbow. ${ }^{7}$

1 Michael Taggart "Proportionality, Deference, Wednesbury" [2008] NZ L Rev 423 ["Proportionality"].

2 Ibid, at 481.

3 Ibid, at 469.

4 Associated Provincial Picture Houses Ltd v Wednesbury Corporation [1948] 1 KB 223 (CA) [Wednesbury].

5 Taggart "Proportionality", above n 2, at 469; see also at 449.

6 Ibid, at 480. Compare David Dyzenhaus, Murray Hunt and Michael Taggart "The Principle of Legality in Administrative Law: Internationalisation as Constitutionalisation" [2001] 1 OUCLJ 5 at 18.

7 Taggart "Proportionality", above n 2, at 477. 
Professor Taggart's contribution to the proportionality vs Wednesbury unreasonableness debate will be picked over and studied carefully. Proponents of monolithic proportionality review will be disappointed by his qualified acceptance of proportionality. ${ }^{8}$ Those pushing variegated unreasonableness or simplified formulations of unreasonableness will be similarly disappointed he proposes the eradication of such developments. ${ }^{9}$ Others will be vexed by the "rights"-"public wrongs" dichotomy and will seek to dissect and critique this instrument of bifurcation. "10 "This sort of line drawing has gone out of fashion", Taggart acknowledged, noting it "can appear formalistic and possibly arbitrary". ${ }^{11}$ His hope, however, was that such bright-line demarcation would help make administrative law more predictable and would encourage "lawyers [to] argue and judges [to] articulate a clear and clearly reasoned position" in borderline cases. ${ }^{12}$

But it was the more inconspicuous parts of his article that piqued my interest: the importance of context and the recognition of variability. I must confess I remain somewhat agnostic on the proportionality debate to which I think Professor Taggart's article will be most obviously fêted. In two short sentences, he captures my main objection to the promotion of proportionality as the panacea for substantive review in administrative law: ${ }^{13}$

Despite appearances to the contrary, proportionality doctrine is no more monolithic than (Wednesbury) unreasonableness. In other words,

8 Domestically, Professor Joseph is one of the key protagonists: see Philip A Joseph Constitutional and Administrative Law in New Zealand (3rd ed, Brookers, Wellington, 2007) at 857. Professor Craig is the leading counterpart on the international stage: see Taggart "Proportionality", above n 2, at 475-476; and see the contribution to this volume: Paul Craig "Proportionality, Rationality and Review" [2010] NZ L Rev 265 ["Proportionality].

9 I probably must confess my membership of this group: Dean R Knight "A Murky Methodology: Standards of Review in Administrative Law" in Claudia Geiringer and Dean R Knight (eds) Seeing the World Whole: Essays in Honour of Sir Kenneth Keith (Victoria University Press, Wellington, 2008) 180 [“A Murky Methodology"].

10 See, for example, Murray Hunt “Against Bifurcation” in David Dyzenhaus, Murray Hunt and Grant Huscroft (eds) A Simple Common Lawyer: Essays in Honour of Michael Taggart (Hart Publishing, Oxford, 2009) 99.

11 Taggart "Proportionality", above n 2, at 469.

12 Ibid, at 470.

13 Ibid, at 465 . Taggart suggests the critical difference is only the burden: proportionality requires the state to justify the limit on any right, whereas unreasonableness imposes the positive duty of proof on the applicant. I have expressed similar views about need for proportionality and intensity to be blended together in order for it to be useful: see Knight "A Murky Methodology", above n 9, at 209-211. For a powerful analysis of the loaded nature of proportionality review, see Grégoire CN Webber "Proportionality, Balancing, and the Cult of Constitutional Rights Scholarship" (2010) 23 CJLJ 179. 
proportionality is a sliding scale of review responding (albeit — potentially - more transparently) to the same contextual and deference factors as variable (Wednesbury) unreasonableness.

This branding of proportionality as inherently variable is teamed with earlier, more general, references to the importance of context. Reminding us that "[i]t has long been recognized that the principles and grounds of judicial review apply differently in many contexts", ${ }^{14}$ Taggart seems to equate this with variable intensity of review. He championed Sir David Williams' pronouncement that "[v]ariability ... is the outstanding feature of judicial review of administrative action". ${ }^{15}$ Indeed, Taggart also explains the same phenomenon in terms of "deference". Administrative law is made up of "a few general (and sometimes conflicting) principles attempting against the odds to hold together an empire comprising vastly disparate subject-matter and processes". ${ }^{16}$ Notably, he suggests the "tension between centralizing principle and pluralism is mediated by large doses of contextualism and deference". ${ }^{17}$

This may all seem somewhat obvious. It is probably as axiomatic as the similar, oft-quoted mantra from Lord Steyn that "[i]n law context is everything". ${ }^{18}$ But I sense a nervousness within the administrative law community, at least in Mike's home country, about these self-evident truths. Certainly, the importance of context is supported, and Lord Steyn's mantra of context is frequently deployed. ${ }^{19}$ There is, though, much scepticism and even outright antipathy - towards the concept of deference or variable intensity of review. Professor Taggart retorts, rightly in my view, that people

14 Taggart "Proportionality", above n 2, at 450.

15 DGT Williams "Justiciability and the Control of Discretionary Power" in Michael Taggart (ed) Judicial Review of Administrative Action in the 1980s: Problems and Prospects (Oxford University Press, Oxford, 1986) 103 at 106; cited in Taggart "Proportionality", above $\mathrm{n} 2$, at 450 .

16 Michael Taggart "Outside Canadian Administrative Law" (1996) 46 UTLJ 649 at 653; repeated in Taggart "Proportionality", above n 2, at 450.

17 Ibid.

$18 R$ (Daly) $v$ Secretary of State for the Home Department [2001] UKHL 26, [2001] 2 AC 532; quoted in Taggart "Proportionality", above n 2, at 450.

19 See for example Unison Networks Ltd v Commerce Commission (2005) 3 NZCCLR 495 (HC) [Unison Networks (HC)] at [7]; Harrison v Auckland City Council [2008] DCR 619 (HC) at [20]; Bovaird and Board of Trustees of Lynfield College v J [2008] NZCA 325, [2008] NZAR 667 at [48]; T v Regional Intellectual Care Agency [2007] NZCA 208, [2007] NZAR 643 at [23]; Wolf v Minister of Immigration [2004] NZAR 414 (HC) [Wolf] at [33]; Air Nelson Ltd v New Zealand Air Line Pilots' Association IUOW Inc [2008] ERNZ 327 (EC) at [22]; Browne v Canwest TV Works Ltd [2008] 1 NZLR 654 (HC) at [73]; R v Hansen [2007] NZSC 7, [2007] 3 NZLR 1 at [115]; Diagnostic Medlab Ltd v Auckland District Health Board [2007] 2 NZLR 832 (HC) at [312]; Powerco Ltd 
cannot have it both ways: "[I]n judicial review contextualism and deference mean much the same thing. You really cannot have one without the other."20 However, tantalisingly, Taggart does not really further explain or expand on this variability thesis - moving instead into a more conceptual discussion of deference. ${ }^{21}$

Against that backdrop, I want to return to the concept of variable intensity of review and the present reticence in New Zealand towards its acceptance. I am reluctant to give up on the variability project. I remain unconvinced that the method of proportionality should trump in the area of rights, especially as proportionality is meaningless without some explicit or implicit calibration of intensity. ${ }^{22}$

I also consider the notion of variable intensity is deeply embedded in present-day judicial methodology, at least in New Zealand. While many of the marquee developments in variable intensity are found in the unreasonableness ground of review, my argument is that this is only one aspect of the variable intensity phenomenon. There are many other judicial techniques which see the paired concepts of contextualism and variability deployed. On a formal level, there are polar views on the desirability of variable intensity of review, at least in relation to the unreasonableness ground. However, the opposition to variable intensity of review sits uncomfortably with the realities of judicial method. Variable intensity of review is commonplace throughout the field of judicial review. It finds its catalyst in the principle of contextualism, which has been widely championed by the New Zealand courts.

When the differing degrees of scrutiny applied by the courts are mapped against a continuum between vigilance and restraint, the appraisal reveals that variable intensity is manifest in different ways. It is manifest within the orthodox grounds of review. It is manifest through the enlargement or restriction of the orthodox grounds of review. It is manifest through the bifurcation of the field of administrative law, where a different approach applies to human rights and public wrongs.

The primary purpose of this article is therefore to demonstrate the widespread application of variable intensity in New Zealand administrative law. The aim is to begin to persuade the naysayers who have objected to (largely, the language of ) variable intensity of review by establishing that at least it is not a fictional phenomenon. The secondary purpose of the article

v Commerce Commission HC Wellington CIV-2005-485-1220, 9 June 2006 at [24]; and Commerce Commission v Bay of Plenty Electricity Ltd (2006) 18 PRNZ 191 (HC) at [2].

20 Taggart "Proportionality", above n 2, at 450.

21 Ibid, at 454-461.

22 I have set out my concerns about proportionality as a monolithic ground in more detail elsewhere: Knight "A Murky Methodology", above n 9, at 209. Professor Craig appears to concede this point: see Craig, above n 8, part IV E (1). 
is to discern the attitudes of local jurists, scholars and practitioners to the contextualism-variability couplet. A strong commitment to the first arm of the couplet is evident, but there are greatly varying attitudes to the latter $\mathrm{arm}$. Some treat it as being self-evident. Others are strongly opposed to it. But the protestations of the latter are refuted by the realities of the survey of judicial methods. Part II of this article focuses on the secondary purpose of the article, by canvassing the attitudes to variability in its overt form. Covert variability is added to the mix in part III, where the focus is on the primary purpose of the article, namely, the more comprehensive understanding of variable intensity.

This examination draws on a similar corpus of cases to those canvassed by Professor Taggart in his article. But, as the search is unhitched from the unreasonableness ground of review, the brief is wider - and more explicitly engages with variability beyond merely the reasonableness ground of review. The ultimate focus is on substance over form. My concern is the actual judicial methodology deployed, rather than the language or justification provided. As with Taggart's article, the examination is grounded in New Zealand, but occasionally peppered with some salient analogies from elsewhere in the common law world. This limited scope is largely pragmatic: personal familiarity, volume and inter-jurisdictional differences mean only a modest exploratory taxonomy is feasible.

In canvassing the existing jurisprudence, I accept Professor Taggart's plea for a schematic. ${ }^{23}$ As he says, "unless we commit to that sort of mapping project the law will continue to be rather chaotic, unprincipled, and resultorientated". ${ }^{24}$ But here I depart from Taggart's rainbow of review, despite my previous experimentation with such a continuum. ${ }^{25} \mathrm{I}$ accept that it is important to demonstrate (based on evidence from decided cases) that the courts engage in variable intensity review, in a manner which plots the degree of scrutiny across the entire map. However, I am not convinced this automatically converts to a framework for determining the degree of scrutiny in future cases. The development of an alternative framework is a bigger, ongoing project beyond the scope of this article. That is, what is the appropriate mechanism or methodology for determining the intensity of review? I worry that the debate about language and the identification of categories and boundaries within the framework has now become so loaded that we are ignoring the more basic question. ${ }^{26}$ What is the method of calibration that is most suitable for modern administrative law?

23 Taggart "Proportionality", above n 2, at 453.

24 Ibid, at 453.

25 Knight "A Murky Methodology", above n 9, at 201.

26 I echo Professor Taggart's thoughts: Taggart "Proportionality", above n 2, at 453. 
Before engaging in the debate about the ideal mechanism to capture and calibrate variable intensity, though, it is helpful to first demonstrate that it is a phenomenon that not only exists but is rife. It is on this preliminary point, at the formative stage of the larger project, that this article seeks to make its contribution. However, to give a sense of the larger project that lies beyond, I conclude in part IV by floating some different ways to think about the process of calibration of intensity based on the present judicial techniques surveyed in this study.

\section{II (Overt) Variable Intensity: An Emerging, But Contentious, Concept}

Variable intensity of review seems to polarise New Zealand scholars, lawyers and judges. Some wholeheartedly endorse it. Others express their disapproval. The notion remains extremely contentious, particularly as it relates to variable forms of unreasonableness. The idea of variable intensity and more intense forms of unreasonableness than Wednesbury's traditional high threshold has a reasonable amount of currency in the High Court and with some members of the Court of Appeal. However, senior judges, particularly those in the Supreme Court, remain hostile. Academic and professional authors have generally wholeheartedly accepted the notion of variable intensity of review, although a few take issue with some of the particular mechanisms within the general rubric of variable intensity.

There are, though, two stories to be told about variable intensity in New Zealand. There is the official response to the explicit or overt forms of variable intensity of review. And then there is the usage of covert variable intensity, deployed through judicial methodologies which manifest different calibrations between judicial vigilance and judicial restraint. The strong commitment of New Zealand courts to contextualism means techniques which involve different degrees of scrutiny are inevitable. But, except for some limited exceptions, the courts are generally quite coy about explicitly embracing the notion of variability or providing any firm scaffolding for its deployment.

Before presenting a taxonomy of the judicial techniques which give effect to variable intensity in part III, it is necessary in this part to set the scene by briefly examining the formal account of variable intensity in New Zealand. As an entry point, an extended exchange with counsel in argument in Ye v Minister of Immigration vividly demonstrates the mood of a number of senior judges: ${ }^{27}$

27 Ye v Minister of Immigration (NZSC, transcript, 21-23 April 2009, SC 53/2008) at 179-182. 
Mr Bassett: If I now can move just to the question of intensity of review, my submission is that this case could have been, and still can be, decided on the application of orthodox judicial review principles, however it is my submission that a hard look approach or a heightened level of intensity of review is nevertheless appropriate in a case such as this, ...

Tipping J: I would hope I would always have a hard look, the question is more, isn't it, to the standard to which you hold the decision making? I don't think it's going to matter much in this case, but honestly, I can't resist the temptation because you obviously have a good grip of this Mr Bassett, to put it to you that the degree of hardness of the look, I wouldn't have thought was the point, it was the degree of the standard to which, in other words, it's almost like degrees of reasonableness, the more fundamental the right, the more reasonable the decision must be. The idea that you look at it more closely, I've never found very helpful.

Elias CJ: I don't know that degrees of reasonableness help either.

Tipping J: No.

Elias CJ: It's just, it's got to be contextual. What is reasonable takes its colour from the context. Really, there's so much dancing around on the heads of pins in this area.

Mr Bassett: I think the lingo, if you like, Your Honour, is a question of deference, less deference where the rights are more fundamental and more deference where it's -

Elias CJ: That's a dreadful word.

Tipping J: It's a controversial word. I understand the concept, you're more exacting, if you like, the more fundamental — it's a more exacting test, or -

Anderson J: It connotes the extent to which a Court's prepared to interfere. Tipping J: Yes.

Anderson J: However you describe it.

Tipping J: And the Court must interfere where it must. You either feel driven to interfere or you don't, and that will depend on what sort of a right it is and what the whole shebang is, I think this is a -

Anderson J: It's really intensity of anxiety.

Mr Bassett: As has just been commented, the reason it's being raised Your Honours is because Justice Chambers and Justice Robertson in the Court of Appeal said that, and indeed Justice Chambers in Huang said that the intensity would be light, to use that adjective, and I think that that — the lightness of review or the lightness of intensity is to some extent bound up with the 
fact that they, in Huang, let section 47(3) occupy the field, if you like. As I understand it, the Court appears to be taking a different view.

Tipping J: Please don't think I'm personally being critical of you at all, I think it's very important that you've raised it, but I'm just saying, I, together with I think the Chief Justice, I think there's a lot of nonsense talked in this area and it's unhelpful to start trying these adjectival or adverbial adornments of the sort of review you're undertaking.

Mr Bassett: Well perhaps, if you ask me the reason why I'm raising it Anderson J: We can see why you're raising it.

Tipping J: We can understand it, I can understand why.

McGrath J: It was a ground, it was specified in the grounds, and no one's blaming you for it.

Tipping J: Yes, no one's blaming you for one moment, we're just — if you can shed some further light on this, but it really does seem to be a more semantic issue that in the end, you interfere if you think you should.

This exchange discloses strong objection to degrees of unreasonableness or attempts to explicitly structure variable intensity of review. The substantive judgment in $Y e$ is also notable for the absence of any direct comment on the notion of variable intensity. ${ }^{28}$

While care must be taken not to make too much of remarks during argument, the attitudes expressed are matched by similar antipathy elsewhere. Although the Supreme Court has not yet explicitly addressed variable intensity in a formal decision on a case, all the pointers suggest it will condemn attempts to explicitly calibrate intensity of review — while at the same time still holding firm to the notion of contextualism. The reticence towards intensity is also manifest in the Court's efforts to sidestep and excoriate arguments made on the basis of variable intensity of review. The reluctance to address the partial adoption of variable intensity by the lower courts must be interpreted as implicit disapproval of the concept. ${ }^{29}$

28 The nearest dictum is the pointed comment from Tipping $\mathrm{J}$ that the "best approach" both for the parties and for the law generally was "to concentrate on the essential points which must be addressed in order to resolve these particular cases" and that the "crucial issues turn on relatively straightforward principles of judicial review": Ye v Minister of Immigration [2009] NZSC 76, [2010] 1 NZLR 104 [Ye] at [11]. Similarly, the companion Huang case simply adopted the bare analysis found in Ye: Huang v Minister of Immigration (Note) [2009] NZSC 77, [2010] 1 NZLR 135 [Huang (SC)] at [1].

29 None of the Judges on appeal grappled with Hammond J's flirtation with the concept in Discount Brands Ltd v Northcote Mainstreet Inc [2004] 3 NZLR 619 (CA); and the 
The Chief Justice is one of the most vocal critics of variable intensity. As can be seen from the exchange in $Y e$, she thinks that deference is a "dreadful" word and the concept of degrees of unreasonableness amounts to "dancing around on the heads of pins". ${ }^{30}$ Elsewhere, she has complained that the idea of a spectrum of unreasonableness was "a New Zealand perversion of recent years" ${ }^{31}$ She has similarly shunned attempts to develop notions of curial deference. In Discount Brands Ltd $v$ Westfield (New Zealand) Ltd, she rejected attempts to argue the propriety of the non-notification of resource consents in terms of intensity. ${ }^{32}$ Her Honour said that the questions turned on "the legislation and its application in context" and were not "helpfully advanced by consideration of the scope and intensity of the High Court's supervisory jurisdiction to ensure reasonableness in substantive result in the exercise of statutory powers". ${ }^{33}$ She has also advocated elsewhere against the exercise of deference in appellate review to factual findings of trial judges. ${ }^{34}$

Dame Sian Elias has also made her views plain extra-judicially. Early addresses demonstrated a strong dislike of Wednesbury's monolithic approach, notably with recognition of judicial review as a continuum and the promotion of a variable "margin of appreciation". ${ }^{35}$ Later, her emphasis

Chief Justice summarily rejected the value of doing so: Discount Brands Ltd $v$ Westfield (New Zealand) Ltd [2005] NZSC 17, [2005] 2 NZLR 597 [Discount Brands]. There was no real discussion of the concept in the following cases, despite the concept being raised by the lower courts: Ye, above n 28; Huang (SC), above n 28; and AttorneyGeneral (Minister of Immigration) v Tamil X [2010] NZSC 107. Despite Hammond J's lament in Lab Tests Auckland Ltd v Auckland District Health Board [2008] NZCA 385, [2009] 1 NZLR 776 about the confusing state of judicial review, leave to appeal was surprisingly refused in that case, on the basis that no arguable question of public or general importance was raised by the appeal. "Each aspect of the case ultimately turns on its own facts", and the Court of Appeal "made no obvious error in its factual assessment": Diagnostic Medlab Ltd v Auckland District Health Board [2009] NZSC 10 (application for leave) [Diagnostic Medlab] at [10].

30 Ye v Minister of Immigration (transcript), above $\mathrm{n} 27$.

31 Astrazeneca Ltd v Commerce Commission (NZSC, transcript, 8 July 2009, SC 91/2008) at 52 .

32 Discount Brands, above n 29.

33 Ibid, at [5].

34 Sian Elias “'A Painful and Uncongenial Obligation'? Appellate Correction of Error of Fact in the Electronic Age" (address to Supreme and Federal Court Judges' Conference, Canberra, 26 January 2010). For the doctrinal prelude, see Austin, Nichols \& Co Inc v Stichting Lodestar [2007] NZSC 103, [2008] 2 NZLR 141. Compare, however, her Honour's willingness to deploy the language of deference, in proceedings challenging the findings made by an electoral body whose decisions were protected by a privative clause: Prem Singh v Krishna Prasad [2003] NZAR 385 (SC of Fiji) at 400.

35 Sian Elias "The Harkness Henry Lecture: 'Hard Look' and the Judicial Function” (1996) 4(2) Waikato L Rev 1 at 17; see also at 14-23. 
returned to contextualism, with a strong dose of simplicity. In her 2008 Sir David Williams lecture, she proclaimed: "Contextual standards apply throughout the law." ${ }^{36}$ However, she records her penchant for uncalibrated judicial discretion. Adopting Lord Cooke's words, "there is no need for any amplification of reasonableness or fairness", she said, as "both [take] their shape from context". ${ }^{37}$ While acknowledging that the New Zealand simplicity project could be knocked as being an "anti-intellectual strand", ${ }^{38}$ Elias CJ makes clear her predilection for this "simpler path" ${ }^{39}$ Her remarks culminate with the endorsement of Williams' own statement of contextualism: "[T]he application of the principles of administrative law can sensibly be considered only with proper regard for the statutory, institutional and broader social or policy context of a particular case." ${ }^{40}$ Finally, similar themes are evident in her tribute to Professor Taggart in the recent Festschrift: ${ }^{41}$ a strong emphasis on context ("judicial supervision must be highly contextual"); ${ }^{42}$ some passing (and mixed) references to the role of deference; ${ }^{43}$ and a plea for simplicity. ${ }^{44}$ Notably, Dame Sian wonders whether a "more nuanced approach" to the absolute deference of Wednesbury will be developed, where more respect is afforded to the assessment of the decision-maker under review "depending on the nature of the decision and the relative institutional competencies of the court and the primary decision-maker" ${ }^{45}$ But, echoing the thoughts of Felix Frankfurter, she warns against over-stratification: "[It is] necessary to

36 Sian Elias “Administrative Law for 'Living People"” (2009) 68 CLJ 47 at 66 [“Administrative Law"].

37 Ibid, at 65. For Lord Cooke's views on simplicity and contextualism, see Taggart "Proportionality", above n 2, at 474. See also Sir David GT Williams "Lord Cooke and Natural Justice", Michael B Taggart "The Contribution of Lord Cooke to Scope of Review Doctrine in Administrative Law: A Comparative Common Law Perspective" ["Scope of Review"], and Janet McLean "Constitutional and Administrative Law: The Contribution of Lord Cooke" in Paul Rishworth (ed) The Struggle for Simplicity in the Law: Essays for Lord Cooke of Thorndon (Butterworths, Wellington, 1997) 177, 189 and 221 respectively; and Dean R Knight "Simple, Fair, Discretionary Administrative Law" (2008) 39 VUWLR 99.

38 Elias "Administrative Law", above n 36, at 48.

39 Ibid, at 66.

40 Ibid; adopting DGT Williams "Criminal Law and Administrative Law: Problems of Procedure and Reasonableness" in P Smith (ed) Criminal Law: Essays in Honour of JC Smith (London, 1987) 170 at 170.

41 Sian Elias "Righting Administrative Law" in David Dyzenhaus, Murray Hunt and Grant Huscroft (eds) A Simple Common Lawyer: Essays in Honour of Michael Taggart (Hart Publishing, Oxford, 2009) 55 ["Righting Administrative Law"].

42 Ibid, at 71.

43 Ibid, at 66-69.

44 Ibid, at 72.

45 Ibid, at 68. 
be on guard against 'an undue quest for certainty, borne of an eager desire to curb the dangers of discretionary power'."'46

Other judges of the Supreme Court are less forthright: they seem to embrace simplicity but remain sceptical about variability, at least in its overt formulation. Blanchard J featured in cases in the 1990s where Wednesbury's high threshold was restated ${ }^{47}$ along with later cases reminding of the contextualism of unreasonableness. ${ }^{48}$ In Discount Brands he deployed a more intense form of review than the Wednesbury standard, but did so without any express reference to the degree of judicial scrutiny. ${ }^{49}$

Similarly, there is little discussion of issues of intensity in judgments penned by Tipping J. ${ }^{50}$ One notable exception is his Honour's willingness to experiment with the idea of a margin of appreciation in a case directly engaging the New Zealand Bill of Rights Act 1990, $R v$ Hansen.${ }^{51}$ Tipping $\mathrm{J}$ raised the idea of a "margin of appreciation" or deference applying to the proportionality calculus required under s 5 of the Bill of Rights Act and suggested it was akin to shooting at a target, the size of which "may differ at different stages of the inquiry" - perhaps an implicit nod to the notion of variability. ${ }^{52}$ A glimpse of Tipping J's colours may perhaps be seen in the exchange in argument in $Y e$, where he pondered whether, as a judge, "you interfere if you think you should". This instinctive approach has some judicial pedigree, ${ }^{53}$ and notably found favour with Lord Cooke. ${ }^{54}$

46 Ibid, at 71; quoting Felix Frankfurter "The Task of Administrative Law" (1926) 75 U Pa L Rev 614 at 619.

47 Wellington City Council v Woolworths New Zealand Ltd (No 2) [1996] 2 NZLR 537 (CA).

48 See Waitakere City Council v Lovelock [1997] 2 NZLR 385 (CA) [Lovelock]; Pring v Wanganui District Council [1999] NZRMA 519 (CA).

49 Discount Brands, above n 29.

50 His separate reasons in Discount Brands speak only to the test for the primary decisionmaker, not the approach required of a reviewing court: ibid, at [142].

$51 R v$ Hansen, above $\mathrm{n} 19$.

52 Ibid, at [119].

53 There is some similarity with the innominate ground adopted by Lord Donaldson in the Guinness case where judicial intervention was treated as being legitimate when "something had gone wrong of a nature and degree which required the intervention of the court": $R v$ Panel on Take-overs and Mergers, ex parte Guinness plc [1989] 1 All ER 509 [Guinness] at 513.

54 Robin Cooke "Fairness" (1989) 19 VUWLR 421 at 426 and Lord Cooke of Thorndon "The Discretionary Heart of Administrative Law" in Christopher Forsyth and Ivan Hare (eds) The Golden Metwand and the Crooked Cord: Essays on Public Law in Honour of Sir William Wade (Clarendon Press, Oxford, 1998) 203. See also Lord Cooke "Foreword" in Philip A Joseph Constitutional and Administrative Law in New Zealand (2nd ed, Brookers, Wellington, 2001) [Joseph (2nd ed)] at vi; and Lord Cooke "The Road Ahead for the Common Law" (2004) 53 ICLQ 273 at 284. 
Justice McGrath has not found it necessary to expressly address questions of intensity, preferring to resolve administrative law questions through the application of apparently orthodox principles. For example, his judgment for the Supreme Court in Unison Networks Ltd v Commerce Commission is notable for his preference to resolve the issue of the limits of a price regulator's power according to "conventional" grounds, there improper purpose and error of law. ${ }^{55} \mathrm{He}$ is an obvious champion of contextualism, though. His recent judgment in the Wyeth (NZ) Ltd v Ancare New Zealand $L t d$ case reiterated that natural justice fair hearing rights "vary with the power which is exercised and the circumstances". 56

Sir Kenneth Keith, since retired from the Court, was not a fan of explicit standards of intensity but was clearly committed to contextualism. ${ }^{57}$ An example is his strong enjoinder in Discount Brands that the critical statutory pre-condition giving rise to the impugned power "must of course be read in context, in particular in the context of the power in question". ${ }^{58}$ The other permanent Supreme Court judges have not featured prominently in administrative law cases. ${ }^{59}$

The Court of Appeal and High Court have been more willing to explore an explicit notion of variable intensity - although the position is far from settled. Some judges regularly resort to the language of variable intensity.

55 Unison Networks Ltd v Commerce Commission [2007] NZSC 74, [2008] 1 NZLR 42 [Unison Networks (SC)], at [52]. The only authorities referred to were (a) Joseph (2nd ed), above n 54; (b) the famous case of Padfield $v$ Minister of Agriculture, Fisheries and Food [1968] AC 997 (HL); and (c) the two New Zealand equivalents: Attorney-General $v$ Ireland [2002] 2 NZLR 220 (CA) and Poananga v State Services Commission [1985] 2 NZLR 385 (CA). But see an alternative account, text at n 144 below. See also the reiteration of the long-standing Newbury District Council $v$ Secretary of State for the Environment [1981] AC 578 (HL) principle in Waitakere City Council v Estate Homes Ltd [2006] NZSC 112, [2007] 2 NZLR 149.

56 Wyeth (NZ) Ltd v Ancare New Zealand Ltd [2010] NZSC 46, [2010] 3 NZLR 569 [Wyeth] at [40]; adopting the words from Cooke J in Daganayasi v Minister of Immigration [1980] 2 NZLR 130 (CA) [Daganayasi] at 141.

57 Compare with his acknowledgement of variable and explicit methodologies of secondary review, and his plea for "[m] ore precise articulation" of the different standards of review, while writing as an academic: KJ Keith "Appeals from Administrative Tribunals: The Existing Judicial Experience" (1969) 5 VUWLR 123 at 151.

58 Discount Brands, above n 29, at [53]. Based on this context, particularly his characterisation of the power to notify or not as a "gate-keeping" decision and engagement of the natural justice protections in the New Zealand Bill of Rights Act 1990, he basically said the court was entitled to assess compliance with the legislative provisions afresh.

59 William Young J; also Anderson J (now retired) and Wilson J (resigned). 
Others pointedly refuse to engage with the notion of explicit variability. In a series of immigration and refugee cases, some members of the Court of Appeal have begun to develop more sophisticated approaches to intensity or standards of review. ${ }^{60}$ However, these views have not always found favour with their fellow judges (nor, as has been seen, with the Supreme Court on appeal) ${ }^{61}$ For example, confronting the impact of the interests of children on removal decisions relating to their parents, Glazebrook J expressly addressed the question of intensity in terms of an applicable standard of review in Ye $v$ Minister of Immigration. ${ }^{62}$ Ultimately, though, she resolved the case through the application of ordinary principles of relevancy and error of law. ${ }^{63}$ In a case arising in similar factual circumstances, Huang $v$ Minister of Immigration, William Young P and Hammond J explicitly addressed the "intensity of review" to be applied. ${ }^{64}$ In Tamil X v Refugee Status Appeals Authority, Baragwanath $\mathrm{J}$ engaged in an extensive survey — drawing on a wide range of international jurisprudence - of the appropriate standard or intensity for review of the factual findings made about complicity in war crimes. ${ }^{65}$ Building on his intensity schema set out in earlier cases, ${ }^{66}$ his Honour concluded that the factual finding should be reviewed on a correctness or de novo standard. ${ }^{67}$ His fellow judges, Hammond and Arnold

60 For a more detailed analysis of this line of cases, see Claudia Geiringer "Ding v Minister of Immigration; Ye v Minister of Immigration" (December 2008) New Zealand Centre for Public Law Working Papers <www.victoria.ac.nz>; Hanna Wilberg "Administrative Law" [2010] NZ L Rev 177 at 193-202.

61 Above, $\mathrm{n} 29$.

62 Ye v Minister of Immigration [2008] NZCA 291, [2009] 2 NZLR 596 [Ye (CA)]. The judgment addressed various appeals from two families - Ye/Ding and Qiu — whose interests mirrored each other. Differently constituted majorities disposed of the appeals: favourably for the Ye/Ding family; unfavourably for the Qiu family. The results are summarised in $\mathrm{Ye}$ (CA) at [358]-[364].

63 Ibid, at [303]-[306]. The other judges avoided the issue of intensity. Hammond and Wilson JJ preferred the error of law route and did not find it necessary to address the question of intensity: ibid, at [403]. Acknowledging Glazebrook J's approach, Chambers and Robertson JJ recorded that they expressed no opinion on the topic of any applicable standard, as in their view it did not arise: ibid, at [569].

64 Huang v Minister of Immigration [2008] NZCA 377, [2009] 2 NZLR 700 [Huang (CA)] at [62]-[67].

65 Tamil Xv Refugee Status Appeals Authority [2009] NZCA 488, [2010] 2 NZLR 73 [Tamil $X(\mathrm{CA})]$ at [259]-[276].

66 See discussion below at $\mathrm{n} 173$.

67 Tamil X(CA), above n 65, at [276]. 
JJ, both avoided generic questions of the standard of review, resolving the case on different bases ${ }^{68}$ (as did the Supreme Court on appeal) ${ }^{69}$

Variable intensity of review has also featured in a number of Court of Appeal decisions addressing review of commercial or "private" decisions of public functionaries, albeit under the slightly different rubric of "scope" of review. (Unlike the decisions discussed so far, there are no supervening Supreme Court decisions in these cases..$^{70}$ ) The focus is on the restriction, not enlargement, of review. Chambers and Arnold JJ spoke of the "limits on the scope of judicial review" when reviewing a pricing decision of an airport company in Air New Zealand Ltd v Wellington International Airport Ltd. ${ }^{71}$ Their ultimate conclusion was that — based on the Mercury Energy ${ }^{72}$ approach where intervention is only permitted in the case of bad faith, corruption or fraud - it was improper to attempt to impugn the decisions on the basis of orthodox grounds of irrationality and relevancy. ${ }^{73}$ Baragwanath $\mathrm{J}$ took the opportunity to record that "the technique of judicial review ... is to apply whatever degree of intensity the subject case warrants" ${ }^{74}$ However, he dissented on the applicable intensity to be deployed, questioning whether "[1]ight-handed ... non-intensive, judicial review" was appropriate. ${ }^{75}$

Similarly, in Lab Tests Auckland Ltd v Auckland District Health Board, Arnold and Ellen France JJ ruled that the commercial context dictated a limited approach to review of a District Health Board's procurement decision. ${ }^{76}$ Their analysis of the applicable "scope of review" is littered

68 Despite receiving "extensive discussion" from counsel on the appropriate standard of review to be employed in such a case, Hammond J considered the appeal could be resolved on a "straightforward and orthodox judicial review basis" without resolution of the generic standard of review question: ibid, at [53] and [55]. Arnold J did not refer to any standard of review, and instead simply resolved the appeal on the basis of error of law and (in)sufficiency of evidence: ibid, at [169]-[171].

69 Above, n 29.

70 Leave to appeal was refused in the second case to be discussed (Lab Tests): see above $\mathrm{n} 29$.

71 Air New Zealand Ltd v Wellington International Airport Ltd [2009] NZCA 259, [2009] 3 NZLR 713 at [45].

72 Mercury Energy Ltd v Electricity Corp of New Zealand Ltd [1994] 2 NZLR 385 (PC) [Mercury Energy].

73 Air New Zealand Ltd $v$ Wellington International Airport Ltd, above n 71, at [76].

74 Ibid, at [131].

75 Ibid, at [136]-[137]. Engaging in an extended contextual analysis for the purpose of determining the approach to intensity of review, his Honour concluded the conduct of the airport company should be measured against the usual irrationality or unreasonableness standard: ibid, at [180]. Ultimately he formed the view that the allegations pleaded fell short of even that threshold: ibid, at [193].

76 Lab Tests Auckland Ltd v Auckland District Health Board [2008] NZCA 385, [2009] 1 NZLR 776 [Lab Tests] at [88]. 
with reference to the court's approach varying with context. ${ }^{77}$ In his separate reasons, Hammond $\mathrm{J}$ also expressly addressed questions of the point of entry for judicial review (connoting limited review in some cases) and the principles of judicial review (lamenting, particularly, that the substantive grounds of review are covered in "fog" of the "pea souper" variety). ${ }^{78} \mathrm{He}$ pointed to problems in the current grounds of review, particularly the "lack of an agreed classification or taxonomy, accompanied by properly developed substantive principles as to when a court will intervene by way of judicial review". ${ }^{79}$ Oddly, though, he doubted the value of embracing the notion of deference. $^{80}$

In the High Court, judges have embraced the concept of variegated forms of unreasonableness, with little dissent. The high threshold of Wednesbury has been explicitly loosened, although the definition of the new standard of reasonableness has not been firmly settled.$^{81}$ In the High Court, concepts like "hard look", "anxious scrutiny", ${ }^{83}$ or simple or intermediate unreasonableness ${ }^{84}$ are now routinely deployed, particularly in immigration cases and those dealing with technical environmental planning cases.

This mixed - and quite polemic — set of judicial views sits uncomfortably with the recognition of variable intensity by the local academic and professional authors. Scholars and professional writers have largely accepted the notion of variable intensity of review, although a few take issue with some of the particular mechanisms within the general rubric of variable intensity.

The specialist text on judicial review - GDS Taylor's Judicial Review: A New Zealand Perspective - devotes an entire chapter to the concept of the "depth" of judicial review. ${ }^{85}$ Taylor introduces this with the basic proposition that judicial review is not a discipline "where the same principles apply across the board" ${ }^{86}$ The more detailed taxonomy of the depth of review

77 Ibid, at [56], [57], [58] and [59].

78 Ibid, at [370] and [384].

79 Ibid, at [380].

80 Ibid, at [379].

81 See Knight "A Murky Methodology", above n 9; and Professor Taggart's own survey: Taggart "Proportionality", above n 2, at 446-450.

82 Pharmaceutical Management Agency Ltd v Roussel Uclaf Australia Pty Ltd [1998] NZAR 58 (CA) at 66 [Pharmac].

$83 R v$ Secretary of State for the Home Department, ex parte Bugdaycay [1987] AC 514 (HL) at 531.

84 Wolf, above n 19. See also Baker v Canada (Minister of Citizenship and Immigration) [1999] SCR 817.

85 See GDS Taylor Judicial Review: A New Zealand Perspective (2nd ed, LexisNexis, Wellington, 2010) chapter 3.

86 Ibid, at 81 . 
incorporates two separate sections addressing, first, "variable intensity of review", and, secondly, "deference". His examination of variable intensity of review tends to focus on the grounds where there has been overt engagement with variable intensity or degrees of scrutiny. ${ }^{87}$ Similar analysis of the contextual or variable approach to unreasonableness is presented under the heading of "What?" - Review of Exceeding the Limits of Power" ${ }^{88}$ Taylor explains the principle of deference as the provision of "greater latitude" by the courts, "restraint" and a "less intense level of review". ${ }^{89} \mathrm{He}$ also acknowledges, without more, that deference is "variable"..$^{90}$ Taylor also notes that limiting the grounds is another judicial technique which affects the depth of review. ${ }^{91}$ In his constitutional and administrative law text, Professor Philip Joseph records that there has been a "rush to embrace the varying intensities of judicial review". ${ }^{92} \mathrm{He}$ is an obvious subscriber to contextualism and variability, ${ }^{93}$ although he discloses a strong preference for proportionality or, as he sometimes describes it, "constitutional review". ${ }^{44}$ Joseph laments, though, the "frenzy of terminologies causing unnecessary complication", and - adopting Professor Taggart's "all the colours of the rainbow" label — points to numerous "terminologies" or "descriptions of points along the review continuum". ${ }^{95} \mathrm{He}$ explains this phenomenon as arising from a vacuum left by the demise of Wednesbury principles, ${ }^{96}$ and concludes that the sliding threshold - or "selective raising and lowering of the review threshold" — is now part of New Zealand's legal tapestry. ${ }^{97}$ The views of local scholars are

87 Judicial decisions in which the hard look doctrine, adequate consideration principle, degrees of intensity, and precedent fact doctrine was relied on are referred to, although the editorial commentary suggests a degree of scepticism about such developments: ibid.

88 Ibid, chapter 14.

$89 \mathrm{Ibid}$, at [3.11] and [3.12]. His taxonomy of deference focuses on those cases where deference has been applied by the courts to decision-makers with particular institutional capacity and special experience: ibid, at [3.10].

90 Ibid.

91 Ibid, at 81 .

92 Joseph, above $\mathrm{n} 8$, at 853 .

93 Ibid, at 821, 824, 832, 853, 857, 931, 936 and 938. Joseph describes "varying intensities and contextual trappings" as judicial review's defining features: ibid, at 932.

94 Philip A Joseph "The Demise of Ultra Vires - Judicial Review in the New Zealand Courts" [2001] PL 354. He argues that its greater sophistication and precision means proportionality ought to supersede the "middle ground" on the review continuum and could lead to the abolition of the ground of irrationality (save for challenges based on "questions that commend special judicial deference or which do not lend themselves to proportionality method" such as assessments of the national interest or rating decisions of local authorities): Joseph, above $n$, at 857-858.

95 Ibid, at 853.

96 Ibid.

97 Ibid, at 936. 
consistent with the increasing recognition from scholars abroad of the role and significance of the concept of variable intensity. ${ }^{98}$

Professional practice guides in New Zealand also speak to the variability of intensity, particularly under the head of unreasonableness. Radich and Hodgson in a Law Society seminar publication suggest one judge "hit the nail on the head ... in a refreshingly straightforward way" when she said "[t]he intensity with which a tribunal's decisions are scrutinised will vary according to the subject matter in hand" ${ }^{99}$ They explain "intensity of review" as the principle that sees the courts "exercise differing degrees of restraint" (or deference) or "scrutinise closely" decisions based on the nature of the decision under review. ${ }^{100}$ The procedural guide, McGechan on Procedure, similarly points to the development of "a less restrictive and more flexible approach to judicial review". ${ }^{101}$ The authors speak of the erosion of the "restrictive, or deferential, approach to judicial review" as the courts "have come to adopt more intense standards of review for a range of decisions". ${ }^{102}$ Notably, it is suggested that once jurisdiction to review is established, "the Courts' approach to review is to assess how intensely, or closely, it will review a decision". ${ }^{103}$ Francis Cooke QC, one of the leading administrative lawyers, is more cautious in his assessment. He notes competing conservative and aggressive schools of judicial thought and wonders if the recent blending of the two has "coincided with the greater emergence of the concept of intensity of review" ${ }^{104}$ He warns against over-analysis though, as "[b]ad decisionmaking invites intervention", ${ }^{105}$ and suggests that focusing on intensity

98 For example, Harlow and Rawlings question the present obsession with the relative merits of proportionality and reasonableness of grounds of review and suggest " [w] hat is really in issue is intensity": Carol Harlow and Richard Rawlings Law and Administration (3rd ed, Cambridge University Press, Cambridge, 2009) at 126 and 137. Similarly, Professor Craig argues that intellectual honesty demands "a better explanation" and "proper articulation of some background theory" for the intensity with which the principles of judicial review are applied: Paul Craig Administrative Law (6th ed, Sweet \& Maxwell, London, 2008) at 642.

99 Paul Radich "Introduction" in Paul Radich and Jessica Hodgson Public Law - the decision making process (New Zealand Law Society seminar publication, Wellington, August 2006) 1 at 6.

100 Jessica Hodgson "Nature of the Decision-Maker and Nature of the Decision" in Radich and Hodgson, ibid, at 11.

101 Andrew Beck and others McGechan on Procedure (online ed, Brookers) at [JAIntro.03].

102 Ibid.

103 Ibid, at [JAIntro.05].

104 Francis Cooke Judicial Review (New Zealand Law Society seminar publication, Wellington, May 2007) at 6.

105 Ibid, at 7. 
"makes life more complicated" and is "an unnecessary elaboration". ${ }^{106}$ Another leading administrative law advocate, Mary Scholtens QC, similarly identifies an increasing prominence being given to variable intensity of review; "the facts and the legal context are always critical to each case", she notes. ${ }^{107}$ In her view, there has been some progress in the clear explanation of "the approach of the court, in particular to the intensity of review and the circumstances in which different approaches, and the consequences of those, will apply", but she suggests more progress could still be achieved. ${ }^{108}$

This paints an awkward picture for a cartographer of variable intensity. On the one hand, there is growing (but not unqualified) recognition of the utility of recognising variable intensity. On the other hand, the senior judges responsible for crafting and supervising jurisprudential principles have made it plain, albeit not yet formally, that they are sceptical about overt variable intensity of review. My intuition is that some of the objection lies in the locus of the developments, namely, within the unreasonableness ground where the deployment of variable intensity has been most profound through varying degrees of unreasonableness. Or the concern may be with how the different degrees of calibration are set or defined. Or the nervousness may arise from the terminology. My argument is that these concerns are misplaced and beside the point. These are possible features of a variable intensity approach - but they are not immutable or essential characteristics. Acceptance of these elements is not a necessary condition to acceptance of variable intensity of review.

\section{Recognising (Both Overt and Covert) Variable Intensity: Mapping the Wider Terrain Between Vigilance and Restraint}

As recorded in the previous section, attitudes towards variable intensity remain mixed. Some judges find it helpful to acknowledge this curial technique. Others don't. This leaves variable intensity in a fragile position. But variable intensity is not confined to the developments that have been canvassed in part II under the banner headline of variable intensity per se. The judicial methodology of variable intensity is more deeply imbedded in our system of judicial culture, albeit more covertly. In this part, I start by constructing an extended definition of variable intensity as a broad range of different curial techniques adopted to give effect to a necessary

106 Francis Cooke "Lest We Forget" in Judicial Review (New Zealand Law Society seminar publication, Wellington, September 2007) 81 at 88.

107 Mary Scholtens “The Judicial Review Landscape" in Litigating Against the Crown (New Zealand Law Society seminar publication, Wellington, April, 2010) 19 at 20.

108 Ibid, at 20. 
compromise between the competing values of vigilance and restraint. Armed with this more comprehensive definition, I map the corpus of New Zealand jurisprudence to draw out examples of variable intensity, both in its overt and covert forms. This survey suggests that variable intensity of review is more widespread than is suggested by the overt references to the concept. The commitment to contextualism that is heralded in New Zealand means the intensity of review varies widely. But the techniques used to capture variable intensity vary as well.

Two themes identified by one of England's leading administrative law silks, Michael Fordham QC, provide suitable markers to explore variable intensity of review: vigilance and restraint. ${ }^{109}$ Although developed to capture some of the themes of judicial supervision, I suggest the two markers represent a helpful way to recognise and map the variation of intensity in individual cases.

Vigilance is driven by the desire to uphold the Rule of Law and to protect the rights, interests and expectations of citizens. ${ }^{110}$ The courts will strive to intervene and are more likely to substitute their view for the view of the decision-maker. One can hear the echoes of Sir William Wade: "The primary purpose of administrative law ... is to keep the powers of government within their legal bounds, so as to protect the citizen against their abuse. The powerful engines of authority must be prevented from running amok." ${ }^{111} \mathrm{Ex}$ post facto judicial control focused on legality is given primacy, narrowly defined. Sometimes this is equated with the "red" light. ${ }^{12}$

On the other hand, restraint is based on the recognition of the separation of powers principle, and recognises the limits of judicial review. First, it acknowledges the constitutional allocation of power by the legislature to public bodies and officials. Courts are only charged with reviewing decisions, not making them (as Fordham describes it, "[t]he 'forbidden' method"). ${ }^{113}$ Secondly, it recognises the limits of the judicial function (public servants are often better equipped to grapple with certain questions than judges). Thirdly, it builds on the notion that judges are only but one of the many accountability

109 Michael Fordham Judicial Review Handbook (4th ed, Hart Publishing, Oxford, 2004) at 270. See also Michael Fordham "Surveying the Grounds: Key Themes in Judicial Intervention" in Peter Leyland and Terry Woods (eds) Administrative Law Facing the Future: Old Constraints and New Horizons (Blackstone Press, London, 1997) 184. Compare the employment of the principle of "weight" by Tom Hickman Public Law after the Human Rights Act (Hart Publishing, Oxford, 2010) at 125.

110 Fordham Judicial Review Handbook, ibid, at [12.1].

111 Sir William Wade and Christopher Forsyth Administrative Law (9th ed, Oxford University Press, Oxford, 2004) at 5.

112 Harlow and Rawlings, above n 98, at 23.

113 Fordham Judicial Review Handbook, above n 109, at 305. 
mechanisms that control public power. These themes of restraint mean the courts will be cautious about intervening and give a reasonable amount of latitude (or deference) to the decision-maker's judgement. Sometimes associated with the green light, ${ }^{114}$ its aim is to facilitate the operations of the state and to improve the effectiveness and efficiency of governance. Courts employing restraint place more faith in ex ante, informal, internal controls of administrative power - greater scepticism about the role of the judiciary is evident. ${ }^{115}$

Of course, neither of the two competing themes necessarily prevails absolutely and most judicial review cases represent a mediated compromise between these two principles (the so called "amber" light). ${ }^{116}$ In my view, the need to accommodate this dynamic tension in individual cases explains why the depth of judicial scrutiny varies according to context. This means one would expect variability to operate across all of the grounds of review, not just in the area of unreasonableness. In this part, I show that this, in fact, is the case.

Mapping New Zealand's overt and covert deployment of variable intensity across all grounds of review against these themes presents a fuller picture of variable intensity. It discloses more frequent resort to variable intensity than is suggested by a narrow examination of variable intensity in its overt form. In general terms, the results can be grouped together based on the different types of context within which it occurs, namely:

(a) variable intensity within the orthodox grounds;

(b) variable intensity in the emerging new substantive grounds, or the revised unreasonableness ground;

(c) variable intensity as a form of primary or secondary non-justiciability; and

(d) variable intensity in the domain of human rights.

\section{A Variable intensity within the orthodox grounds}

To a certain degree, the orthodox grounds of review encapsulate an "offthe-shelf" balance between the competing themes, at least in simple cases. Whether one adopts the tripartite principles of good administration

114 Harlow and Rawlings, above n 98, at 31.

115 Ibid, at 1-48.

116 Carol Harlow and Richard Rawlings Law and Administration (2nd ed, Butterworths, London, 1997) chapter 4. Sadly, the amber light metaphor has not survived the third edition: see Harlow and Rawlings, above, n 98, chapter 1. 
expressed by Lord Cooke ("in accordance with law, fairly and reasonably") ${ }^{117}$ or Lord Diplock's negative formulation from Council of Civil Service Unions v Minister for the Civil Service (GCHQ) (illegality, irrationality, and procedural impropriety), ${ }^{118}$ each of these principles or grounds contains prescribed degrees of intensity. These grounds are often teamed with the Chief Constable v Evans mantra that the judicial review is about "process not merits", ${ }^{119}$ as in seen in New Zealand's judicial review bible for bureaucrats - The Judge Over Your Shoulder. ${ }^{120}$

In relation to the "illegality" ground, the courts are absolutely vigilant in ensuring the proper interpretation of law. ${ }^{121}$ It is part of their constitutional role as "interpreters of the written law and expounders of the common law" as Cooke J said in Bulk Gas Users Group v Attorney-General. ${ }^{122}$ No latitude is afforded and decision-makers must correctly understand and apply the law. ${ }^{123}$ That is, they must act with a correct interpretation of statutory power, be faithful to its implied purpose and must consider the relevant, legally mandated considerations as well as disregard irrelevant ones. The North American approach, where some form of deference or latitude applies to some questions of law, has gained no traction in New Zealand, despite Professor Taggart urging consideration of such an approach. ${ }^{124}$

Under the head of "procedural impropriety", the courts feel comfortable and empowered to address questions of process and are extremely vigilant to ensure that the hearing and deliberation processes are faithfully observed, particularly where the process in issue is similar to a court-like process. The courts are careful to ensure the decision-maker has provided a fair hearing and the decision is not tainted by bias.

In contrast, Wednesbury's approach builds in "latitude" or "margin of discretion" for the decision-maker under the "irrationality" ground and only mandates intervention in extreme cases of abuse. These are the famous "four

117 Robin Cooke "The Struggle for Simplicity in Administrative Law" in Michael Taggart (ed) Judicial Review of Administrative Action in the 1980s: Problems and Prospects (Oxford University Press, Auckland, 1986) ["Struggle for Simplicity"] 1 at 5.

118 Council of Civil Service Unions v Minister for the Civil Service [1985] AC 374 (HL) $[G C H Q]$ at 410.

119 Chief Constable of the North Wales Police v Evans [1982] 1 WLR 1155 (HL) at 1165.

120 Crown Law Office The Judge Over Your Shoulder: A Guide to Judicial Review of Administrative Decisions (Crown Law Office, Wellington, 2005) at [7].

121 See Professor Taggart's critique of this approach: Taggart "Scope of Review", above n 37. For a recent update, see Wilberg, above n 60, at 191-193.

122 Bulk Gas Users Group v Attorney-General [1983] NZLR 129 (CA) [Bulk Gas] at 133.

123 Peters $v$ Davison [1999] 2 NZLR 164 (CA).

124 Taggart "Scope of Review", above n 37. See the seminal cases of Canadian Union of Public Employees Local 963 v New Brunswick Liquor Corp [1979] 2 SCR 227 [CUPE] and Chevron USA Inc v Natural Resources Defense Council Inc 467 US 837 (SC 1984). 
corners" of discretion, within which courts should not stray. ${ }^{125}$ Restraint is exercised in relation to any of those matters which are considered to amount to, or are closely aligned with, the "merits" of a decision: fact-finding, judgement, discretion, weight and balancing.

This is trite and unexceptional. This is the classic model of judicial review. ${ }^{126}$ As Professor Taggart observed, "the trichotomy between review of fact, law, and discretion is well known, and the different standards of review in each category reflect functional, institutional, and pragmatic considerations, as well as legitimacy concerns". ${ }^{127}$ For present purposes, the general approach is the important element; formal and defined (categorical or "doctrinal") ${ }^{128}$ grounds of review with implicit intensity of review. There is no overt room for any variation in intensity, apart from the classification of the complaint under each of those grounds.

In trickier cases, though, the tripartite grounds overlap, merge and tend to break down. ${ }^{129}$ In Professor Taggart's words, "many of the dichotomies upon which administrative law has rested - appeal/review, merits/legality, process/substance, discretion/law, law/policy, fact/law — are no longer seen as giving as much guidance as they once did". ${ }^{130}$ Similarly, picking up some similar themes, the Chief Justice spoke recently of a "repositioning of administrative law", where "[o]ld boundaries, always porous", between law and policy, fact and law, process and substance, private and public, legislative and administrative "with which [the courts] have tried to provide bright lines and rules" need to be reconsidered or re-justified. ${ }^{131}$ At a practical level, as even the recent edition of The Judge Over Your Shoulder acknowledges, it is sometimes "difficult to completely sever" process from the merits. ${ }^{132}$

The problems of a categorical approach based around fictional bright lines were alluded to by Professor Taggart in his article. Even in this simpler world a categorical approach provides a subtle tool for judges to covertly

125 Wednesbury, above $\mathrm{n} 4$, at 228.

126 Carol Harlow "A Special Relationship? American Influences on Judicial Review in England" in Ian Loveland (ed) A Special Relationship? American Influences on Public Law in the UK (Clarendon Press, Oxford, 1995) 79 at 83; adopted by Michael Taggart in "Reinventing Administrative Law" in Nicholas Bamforth and Peter Leyland (eds) Public Law in a Multi-Layered Constitution (Hart Publishing, Oxford, 2003) 311 at 312.

127 Michael Taggart “Administrative Law” [2006] NZ L Rev 75 at 82.

128 Taggart "Proportionality", above n 2, at 481.

129 Even Cooke P acknowledged that his tripartite grounds tended to merge or overlap: New Zealand Fishing Industry Association Inc v Minister of Agriculture and Fisheries [1988] 1 NZLR 544 (CA) at 552.

130 Taggart "Administrative Law", above n 127, at 83.

131 Sian Elias "Righting Administrative Law", above $\mathrm{n} 41$.

132 Judge Over Your Shoulder, above n 120, at [12]. 
deploy variable intensity. Five examples illustrate the subtle exercise of vigilance or restraint within the doctrinal grounds.

First, the classification of an error as one of law or fact effectively dictates vigilant or more restrained scrutiny respectively. If the error is one of law, then the court can express its own view on whether the decision is correct. ${ }^{133}$ If it is a factual error, then as an act of fact-finding or the "merits", the deferential Wednesbury standard applies to it. But distinguishing between the two is never easy. ${ }^{134}$ The often cited example is a situation where an entitlement to government assistance hinges on whether someone is living in "accommodation", and assistance is declined because a person is living in a guest house without cooking or laundry facilities. ${ }^{135}$ Is it an error of law about the meaning of "accommodation"? Or a factual error, where the room has wrongly been classified as accommodation? Different conclusions are reasonably available, and choices available to judges depending on whether they favour restraint or vigilance in the particular circumstances. Similar outcomes are evident when confronting problems in the fact-finding process that are capable of being interpreted either as a procedural defect or something awry with the merits. ${ }^{136}$

Secondly, old-fashioned ideas about some factual errors negating a public body's or official's jurisdiction may see a vigilant approach adopted, but not always. As explained above, fact-finding is traditionally seen as the "merits" and subject to Wednesbury unreasonableness. Sometimes, however, the legislative framework dictates that the presence of a particular fact is a pre-condition to the exercise of a statutory power: certain administrative action is only permitted if a particular fact is established. For example, if a refugee has "committed a war crime", ${ }^{137}$ if a local authority has "adequate information" 138 about environmental effects, or if "it is desirable for the protection of shareholders ... or the public interest". ${ }^{139}$ In the absence of that particular factual circumstance, the public body or official has no jurisdiction (viz legal power) to act. Depending on the nature of the factual pre-condition (and surrounding context), the courts have applied different approaches to

133 See Bulk Gas, above n 122.

134 See Bryson v Three Foot Six Ltd [2005] NZSC 34, [2005] 3 NZLR 721; Timothy Endicott "Questions of Law" (1998) 114 LQR 292; Paul Craig "Judicial Review, Appeal and Factual Error" [2004] PL 788; and Rebecca Williams "When is an Error not an Error? Reform of Jurisdictional Review of Error of Law and Fact" [2007] PL 793.

135 Puhlhofer v Hillingdon London Borough Council [1986] 2 WLR 259 (HL).

136 This is one account of Keith J's strict approach in Discount Brands: see text above at n 29.

137 Tamil X(CA), above n 65.

138 Discount Brands, above n 29.

139 Hawkins $v$ Minister of Justice [1991] 2 NZLR 530 (CA) [Hawkins] at 537. 
reviewing such fact-finding: vigilant approaches emphasising the lack of legal power in some cases; judicial restraint, emphasising the evaluation and judgement in the fact-finding process in others. The range of approaches include: (a) insisting that the public body or official must have correctly determined the factual question, in the eyes of the court (effectively, the old-fashioned "jurisdictional fact" doctrine) ${ }^{140}$ (b) only requiring that the public body or official's factual finding was reasonable, perhaps only in the simple sense; and (c) only requiring that the public body or official's factual finding was not manifestly unreasonable. ${ }^{141}$ Variability once again.

Thirdly, even within the error of law ground, some of the sub-grounds involve curial techniques which lead to differing scrutiny depending on the context. Under the traditional model, the resolution of a question of law - the determination of meaning and purpose - is where we usually see absolute vigilance. ${ }^{142}$ That is, a public body or official must operate with fidelity to the purpose of legislation as determined by the courts. ${ }^{143}$ However, when divining the purpose of legislation, the courts face a choice. They can construe the purpose in broad or narrow terms. In practical terms, a broadly defined purpose leads to more restrained review; a narrowly set purpose inevitably leads to greater, more vigilant scrutiny of a public body's or official's actions. An example of a deferentially framed purpose is found in the Supreme Court's decision in Unison Networks. ${ }^{144}$ As noted earlier, McGrath J sought to resolve the case on "orthodox" grounds, re-affirming the long-standing purpose principle. ${ }^{145}$ However, when applying this principle, he imputed a broad, open-textured purpose to the legislation. ${ }^{146}$ In setting the implied parameters in a generous way, the Court allowed the Commerce Commission greater scope to make policy choices about the appropriate threshold for controlling electricity line companies. ${ }^{147}$ Or, in other words, it applied a more restrained intensity of review.

Fourthly, even where the matters under review relate to process, the courts are beginning to promote the possibility of latitude towards procedural judgements made by some public bodies and officials in some narrow contexts.

140 Tamil X (CA), above n 65, and $r$ (JM) v Croydon London Borough Council [2009] EWHC 2474 (Admin), [2010] 1 All ER 469 (QBD).

141 Hawkins, above n 139.

142 Bulk Gas, above n 122; Peters v Davison, above n 123.

143 Padfield $v$ Minister of Agriculture, Fisheries and Food, above n 55; Unison Networks (HC), above $\mathrm{n} 19$.

144 Unison Networks (SC), above n 55, at [55] and [64]. I am grateful to Hanna Wilberg for exchanges which have helped illuminate this account. See her own analysis: Wilberg, above $\mathrm{n} 60$, at $189-190$.

145 Unison Networks (SC), above n 55, at [55].

146 Ibid, at [64].

147 Ibid, at [77]. 
The courts have traditionally been emboldened by the "process, not merits" mantra in Chief Constable of the North Wales Police v Evans, ${ }^{148}$ and have taken this as an injunction to ensure the decision-making process followed is entirely proper, in their own eyes. ${ }^{149}$ At the same time, the courts have been alert to the notion that a proper process must depend on the particular context. Common law natural justice is ultimately contextual. ${ }^{150}$ Or, rather, variable. But the courts will, ex post facto, have the final say on whether the fair hearing rights afforded were the proper ones contemplated by the particular situation. This has led to a frustrating position for administrators, as Professor Rawlings notes: "Flexible natural justice, or 'fairness', has come to have no fixed or settled content that an administrator should know must be observed in exercising decision-making powers."151

There are signs, though, that the courts might be willing to provide some latitude to decision-makers when navigating this procedural quagmire. McGrath J's recent decision in Wyeth hints at a departure from strict review of the process by the courts, over and above the usual contextual approach to the determination of proper process in each particular case. ${ }^{152}$ In Wyeth the Supreme Court was called on to consider a competitor's request for access to confidential information in a contested approval process under the Hazardous Substances and New Organisms Act 1996. ${ }^{153}$ The Court said that the Environmental Risk Management Authority's policy, which sought to balance "the confidential nature of information concerning new hazardous substances and organisms ... and the statutory objective of providing for full and informed public participation in the approval process", ${ }^{154}$ could not be faulted, nor was its application erroneous in a general sense. ${ }^{155}$ Notably, though, the language of McGrath J's analysis at times suggests a deferential approach to the assessment of the proper

148 Chief Constable of the North Wales Police v Evans [1982] 1 WLR 1155 (HL) at 1161.

149 Taylor, above $\mathrm{n}$ 85, at [13.01], [13.02] and [13.40].

150 See, for example, Furnell v Whangarei High Schools Board [1973] 2 NZLR 705 (PC); Daganayasi, above n 56; and Lord Woolf, Jeffrey Jowell and AP Le Sueur De Smith, Woolf \& Jowell's Principles of Judicial Review (London, Sweet \& Maxwell, 1999) at [8-002].

151 HF Rawlings "Judicial Review and the "Control of Government" (1986) 64 Public Administration 135 at 141.

152 Wyeth, above $\mathrm{n} 56$.

153 Any ruling on the point was complicated by the applicant for approval failing to participate in the appeal to the Supreme Court, meaning that the Court effectively issued an advisory opinion in the abstract rather than a ruling on a live controversy: ibid, at [56].

154 Ibid.

155 Ibid, at [55] and [57]-[58]. 
process, emphasising the evaluative judgement involved in balancing the interests. ${ }^{156}$

Two decisions reviewing actions of local authorities similarly intimate a more restrained approach, where local authorities might be afforded more latitude when constructing deliberative processes. Justice Duffy adopted a light-handed approach in Whakatane District Council v Bay of Plenty Regional Council when reviewing the process adopted by the local authority for deliberating on a (controversial) proposal to relocate its offices. ${ }^{157}$ Prompted by a quite novel statutory framework of public participation and deliberation, she accepted that the local authority was required to "create a procedural template" giving effect to the requirements of the framework, but noted that "the form it takes is left to the local authority's discretion". ${ }^{158} \mathrm{Her}$ sympathetic approach was, however, overturned on appeal, with the Court of Appeal effectively ruling that strict compliance was required, despite the provision for moderating judgements in the legislative scheme. ${ }^{159}$

In Goulden v Wellington City Council, Goddard J was likewise quite deferential when scrutinising the process adopted by a mayor and governing body of the local authority to discipline a fellow member for breaching its code of conduct. ${ }^{160}$ The decision to refer the complaint to an extraordinary meeting and to attenuate the notice was "an eminently reasonable decision in the circumstances ... [and] very much within her province as mayor". ${ }^{161}$ Similarly, the process at the meeting fairly balanced the councillor's rights with the local authority's role and its ability to hold meetings "it believes are necessary for the good government of its district". ${ }^{162}$

Finally, the influence of international instruments on domestic administrative law presents a further opportunity for variable intensity of review. ${ }^{163}$ Two dominant methodologies exist to assess the proper impact of international norms on the decisions of public bodies and officials: the relevancy model and the presumption of consistency model. The relevancy model sees the

156 Ibid, at [47]-[49]. This is reinforced by the fact the Court did not rule on whether the natural justice obligations were "correctly applied" in the Authority's decision, and otherwise seemed to focus on whether the approach was open to the Authority: ibid, at [56].

157 Whakatane District Council v Bay of Plenty Regional Council [2009] 3 NZLR 799 (HC) [Whakatane District Council (HC)].

158 Ibid, at [46].

159 Whakatane District Council v Bay of Plenty Regional Council [2010] NZCA 346.

160 Goulden v Wellington City Council [2006] 3 NZLR 244 (HC).

161 Ibid, at [49].

162 Ibid, at [50]-[51].

163 Professor Taggart suggested the developments in this area were evidence of the breakdown of the law and discretion dichotomy: Taggart "Administrative Law", above $\mathrm{n} 127$, at 83 . 
courts checking whether a public body or official has correctly identified whether the legal or factual circumstances require international norms be taken into account. ${ }^{164}$ However, as mandatory relevant considerations only, the weight given to those international law norms in the ultimate decision remains a matter for the public body or official. In contrast, the presumption of consistency model effectively circumscribes the discretion available to public bodies or officials. ${ }^{165}$ Mimicking the principle of legality, the presumption of consistency is interpretative. It allows the courts to insist that international law norms be given effect in the decision by grafting the international obligation onto the domestic statute, except where the statutory matrix is otherwise inconsistent. While the vigilant presumption of consistency approach seems to be gaining in ascendency, the more deferential relevancy model remains appropriate for some circumstances. This posits another form of variable intensity of review under the legality ground of review.

As has been shown, even the categorical or doctrinal grounds of review contain some implicit variability. However, the mechanisms by which this is deployed are much more subtle and covert.

\section{B Variable intensity in the emerging or revised grounds}

Variable intensity is, of course, most profound in judicial review's twilight zone, where the courts have sought to circumvent Wednesbury's high threshold through the development of alternative substantive grounds or the revision of the existing reasonableness ground.

\section{(1) Revision of the reasonableness ground}

The courts have experimented with different formulations of the reasonableness ground:

(a) a simple but universal form of unreasonableness; ${ }^{166}$

(b) an intermediate category of simple unreasonableness; ${ }^{167}$

164 See Ashby v Minister of Immigration [1981] 1 NZLR 222 (CA) and Tavita v Minister of Immigration [1994] 2 NZLR 257 (CA). See also Claudia Geiringer "Tavita and All That: Confronting the Confusion Surrounding Unincorporated Treaties and Administrative Law" (2004) 21 NZULR 66.

165 Puli'uvea v Removal Review Authority [1996] 3 NZLR 538 (CA); Zaoui v AttorneyGeneral (No 2) [2005] NZSC 38, [2006] 1 NZLR 289; and Ye, above n 28.

166 Cooke "Struggle for Simplicity", above n 117; Lovelock, above n 48, at 403-405 per Thomas J.

167 Wolf, above $\mathrm{n}$ 19. See also the development of reasonableness simpliciter, albeit in relation to questions of both law and discretion, in Canada (Director of Investigation \& 
(c) a number of categories of unreasonableness or substantive review, each with varying intensity; ${ }^{168}$

(d) greater intensity of review (or "hard look") under the reasonableness ground, based on a sliding scale or undefined continuum. ${ }^{169}$

As these developments amount to a departure from the classic formulation of Wednesbury unreasonableness, it seems most appropriate to classify them as either the revision of the existing ground of unreasonableness or the development of a new independent ground (or grounds) of review. For present purposes, the distinction is not significant. They involve the application of greater vigilance beyond the existing off-the-shelf calibrations of the orthodox grounds of review.

In the 1980s and 1990s, Lord Cooke was most prominent in the crusade against Wednesbury, particularly in the campaign for a simple but universal form of unreasonableness. ${ }^{170}$ More recently, though, the developments have been driven by two judges in a series of High Court judgments. In addition, there has been some recognition of contextual forms of unreasonableness in the Court of Appeal, but more limited deployment of variegated forms of unreasonableness.

In the High Court, Justice Wild's attempt in Wolf $v$ Minister of Immigration to authoritatively endorse the concept of the sliding scale of unreasonableness and an intermediate standard of simple unreasonableness stands as the leading decision. ${ }^{171} \mathrm{He}$ said "the time has come to state - or really to clarify - that the tests as laid down in GCHQ and Woolworths respectively are not, or should no longer be, the invariable or universal tests of 'unreasonableness' applied in New Zealand public law". ${ }^{172}$ While he was on the High Court, Baragwanath $J$ was also at the vanguard of such developments, with his attempts to develop a multi-layered, and rather complicated, schema. ${ }^{173}$ Numerous other High Court judges have also found

Research) v Southam Inc [1997] 1 SCR 748.

168 See the discussion of Baragwanath J's schema, text at n 173 below.

169 Pharmac, above $\mathrm{n} 82$, at 66; and cases at $\mathrm{n} 174$ below.

170 See above $\mathrm{n} 37$.

171 Wolf, above n 19.

172 Ibid, at [47]; referring to GCHQ, above n 118 and Woolworths, above n 47.

173 See particularly, Ports of Auckland Ltd v Auckland City Council [1999] 1 NZLR 601 (HC); Tupou v Removal Review Authority [2001] NZAR 696 (HC); and Progressive Enterprises v North Shore City Council [2006] NZRMA 72 (HC). These developments are summarised in Knight "A Murky Methodology", above n 9, at 188-189. See also the extended analysis in Mihos v Attorney-General [2008] NZAR 177 (HC). For further engagement with variable intensity during his Honour's brief promotion to the Court of Appeal, see text at n 65 above. 
comfort in the more intense form of unreasonableness, however defined. ${ }^{174}$ Thus in the High Court, as I have noted elsewhere, "a sliding-scale of unreasonableness has replaced the previously all-embracing Wednesbury standard". ${ }^{175}$ A notable, but rare, critic has been Fogarty J, who remains sceptical about variable intensity despite accepting contextualism. "Glossing this natural diversity of judicial review process, with notions of the Court's scrutinising legality more or less carefully," he says, "is difficult to grasp conceptually." 176

The Court of Appeal has for a long time hinted at the concept of contextualism evident in unreasonableness. However, this has more recently converted to explicit consideration of standards or intensity of review, albeit with some dissonance. The prospect of a contextual and "less-restrained" approach to unreasonableness was acknowledged by one of the majority judgments in Waitakere City Council v Lovelock, with a reminder that a court's approach must be "flexible" as well as "sensitive to the realities of the situation under review". ${ }^{177}$ The Lovelock decision is also memorable for Thomas J's extended homily about unreasonableness, where he joined those calling on the exaggerated Wednesbury test to be exterminated and replaced with a simplified and transparent standard for unreasonableness. ${ }^{178}$ The idea of greater intensity than Wednesbury's high threshold being employed was also canvassed in Pharmaceutical Management Agency Ltd $v$ Roussel Uclaf Australia Pty Ltd ${ }^{179}$ and Pring v Wanganui District Council. ${ }^{180}$ Similar remarks were made in the Court of Appeal's decision in Discount Brands Ltd $v$ Northcote Mainstreet Inc. ${ }^{181}$ Hammond J noted that "the depth of

174 See, for example, $B$ v Commissioner of Inland Revenue [2004] 2 NZLR 86 (HC); $A v$ Chief Executive of the Department of Labour HC Auckland CIV-2004-404-6314, 19 October 2005; Northcote Mainstreet Inc v North Shore City Council [2006] NZRMA 137 (HC); Huang Xiao Qiong v Minister of Immigration [2007] NZAR 163 (HC); Wright $v$ Attorney-General [2006] NZAR 66 (HC); Sv Chief Executive of the Department of Labour [2006] NZAR 234 (HC); and Dunne v CanWest TVWorks Ltd [2005] NZAR 577 (HC).

175 Knight "A Murky Methodology", above n 9, at 193.

176 Gordon v Auckland City Council HC Auckland CIV-2006-404-4417, 29 November 2006 at [11].

177 Waitakere City Council v Lovelock [1997] 2 NZLR 385 (CA), at 419-420.

178 Ibid, at 402-403.

179 See Pharmaceutical Management Agency Ltd v Roussel Uclaf Australia Pty Ltd [1998] NZAR 58 (CA) [Pharmac]. In his dissent Thomas J addressed the issue as one of inconsistency or lack of even-handedness.

180 See Pring $v$ Wanganui District Council [1999] NZRMA 519 (CA).

181 See Discount Brands Ltd v Northcote Mainstreet Inc [2004] 3 NZLR 619 (CA) [Discount Brands (CA)]. 
administrative law review has been said to vary with context", ${ }^{182}$ although he ultimately adopted the orthodox Wednesbury case for the particular decision under review (an approach which was later overturned by the Supreme Court). The Court of Appeal has also recently emphasised the need for deference towards the judgements of elected local members when grappling with the appropriate limits of bylaws. In Conley v Hamilton City Council, Hammond J suggested that "a court should be very slow to intervene, or adopt a high intensity of review" when reviewing decisions of local authorities involving choices which are "distinctly ones of social policy". ${ }^{183}$

(2) New alternative grounds of substantive review

The courts have also sought to circumvent Wednesbury's high threshold and apply greater vigilance through a number of alternative grounds of review:

(a) substantive legitimate expectation;

(b) inconsistent treatment;

(c) disproportionality; and

(d) substantive fairness.

It is probably fair to say that only substantive legitimate expectation has nowadays crystallised as an accepted alternative ground. The development of the doctrine of substantive legitimate expectation in the seminal case of $R v$ North and East Devon Health Authority, ex parte Coughlan was quite explicitly developed on the back of dissatisfaction with the Wednesbury threshold. ${ }^{184}$ Its potential has been recognised in New Zealand, although claims usually fail on the preliminary question of whether a reasonable expectation exists. ${ }^{185}$

The other emerging grounds remain in strange states of metamorphosis. Most New Zealand courts have rejected the idea of a free-ranging proportionality ground, ${ }^{186}$ except in particular circumstances such as pure New

182 Ibid, at [50].

183 Conley v Hamilton City Council [2007] NZCA 543, [2008] 1 NZLR 789 [Conley] at [75].

$184 R v$ North and East Devon Health Authority, ex parte Coughlan [2001] QB 213 (CA) [Coughlan].

185 Challis v Destination Marlborough Trust Board Inc [2003] 2 NZLR 107 (HC) and New Zealand Association for Migration and Investments Inc v Attorney-General [2006] NZAR 45 (HC). See also Wilberg, above n 60, at 207-213.

186 See Taggart "Proportionality", above n 2, at 441-445. Since that article, see also the possible equation of "anxious scrutiny" with proportionality by Glazebrook J in Ye (CA), above $\mathrm{n}$ 62, at [303] and [306]; and doubts about the appropriateness of this approach 
Zealand Bill of Rights Act 1990 cases (as Professor Taggart recognised in his bifurcated account); ${ }^{187}$ cases involving disproportionate penalties; ${ }^{188}$ and, perhaps, cases involving challenges to local authority bylaws. ${ }^{189}$

Inconsistency has only partly been recognised, as a touchstone of unreasonableness. ${ }^{190}$ Further, (Cookeian) substantive fairness - once in vogue in the late 1980s and early 1990s - has probably now been overtaken by the variegated forms of unreasonableness. ${ }^{191}$

In any event, regardless of the extent of endorsement, these emerging grounds represent some potential for greater judicial vigilance. For present purposes, the significant aspect is that variable intensity is expressed through the deployment in some circumstances of alternative grounds of review that contain built-in intensity that is different — and more intensive — than the orthodox grounds of review.

\section{Variable intensity as a form of primary or secondary non-justiciability}

One of the other common judicial techniques which embraces variable intensity of review is the circumscription of the orthodox grounds of review in particular cases. This approach has been widely endorsed throughout the judicial hierarchy, although the courts have been slow to connect this methodology with other developments in variable intensity. Professor Taggart included full and limited forms of non-justiciability in one of his early rainbows of review, in a rather understated way without amplification. ${ }^{192}$ Domestic courts have openly departed from the orthodox grounds of review in a number of cases in favour of more deferential thresholds for judicial

in these types of cases by William Young P and Hammond $\mathrm{J}$ in the companion case of Huang (CA), above n 64, at [62]-[67].

$187 R v$ Hansen, above $\mathrm{n} 19$ and Moonen v Film and Literature Board of Review [2002] 2 NZLR 754 (CA).

$188 R$ v Barnsley Metropolitan Borough Council, ex parte Hook [1976] 1 WLR 1052 (CA) and Institute of Chartered Accountants of New Zealand v Bevan [2003] 1 NZLR 154 (CA).

189 McCarthy v Madden (1914) 33 NZLR 1251 (SC); Conley, above n 183; and Dean Knight "Brothels, Bylaws, Prostitutes and Proportionality" [2005] NZLJ 423.

190 Pharmac, above n 179; Isaac v Minister of Consumer Affairs [1990] 2 NZLR 606 (HC) and Murphy v Rodney District Council [2004] 3 NZLR 421 (HC).

191 Thames Valley Electric Power Board v NZFP Pulp \& Paper Ltd [1994] 2 NZLR 641 (CA); Northern Roller Milling Co Ltd v Commerce Commission [1994] 2 NZLR 747 (HC); Melissa Poole "Legitimate Expectation and Substantive Fairness: Beyond the Limits of Procedural Propriety" [1995] NZ L Rev 426.

192 Taggart "Administrative Law", above n 127, at 84-85. See a similar approach in Andrew Le Sueur "The Rise and Ruin of Unreasonableness?" [2005] 10 JR 32. 
intervention (or a proscription on any judicial intervention). In some cases, the deployment of limited forms of justiciability has been undertaken under the label of "scope" of review. ${ }^{193}$ In other cases it is treated as being a preliminary or jurisdiction matter, quite separate from the grounds of review. ${ }^{194}$ Obviously, though, this circumscription of the traditional doctrinal grounds for intervention is an example of judicial restraint. This may manifest itself as "primary non-justiciability", where the question is deemed to be incapable of review at all. ${ }^{195}$ Alternatively, it may manifest itself as "secondary non-justiciability", where review is allowed but on more limited grounds than usual.

The principle of primary non-justiciability is most famously seen in New Zealand in Curtis v Minister of Defence. The Court of Appeal avoided the question of the legality of the disbanding of the air strike force, largely because it was a political question which the government of the day should be held accountable for through political — not legal — processes. ${ }^{196}$ Matters preliminary to the passing of legislation are also treated by the domestic courts as being non-justiciable in an absolute sense. ${ }^{197}$ Some exercises of the royal prerogative still remain non-justiciable. ${ }^{198}$

The principle of secondary non-justiciability is most rife in areas at the margins, where the courts have gently expanded the matters subject to review beyond traditional institutional bounds. The Privy Council's decision in Mercury Energy Ltd v Electricity Corp of New Zealand Ltd set the foundation for the varying of the grounds of review available when reviewing the actions of quasi-public/quasi-private bodies. ${ }^{199}$ Confronted with a challenge to commercial decisions of state-owned enterprises (SOEs), the Privy Council famously doubted that such decisions would be reviewable in the absence of "fraud, corruption or bad faith". ${ }^{200}$

193 See text above at $\mathrm{n} 68$.

194 Curtis v Minister of Defence [2002] 2 NZLR 744 (CA) [Curtis] at [26]-[28].

195 For the distinction between "primary" and "secondary" justiciability, see BV Harris "Judicial Review, Justiciability and the Prerogative of Mercy" (2003) 62 CLJ 631.

196 See Curtis, above n 194.

197 Te Runanga o Wharekauri Rekohu Inc v Attorney-General [1993] 2 NZLR 301 (CA); Milroy v Attorney-General [2005] NZAR 562 (CA); and New Zealand Maori Council v Attorney-General [2007] NZCA 269, [2008] 1 NZLR 318.

198 The prospect of some prerogative powers continuing to be non-justiciable, depending on their subject-matter, was left open in GCHQ, above n 118; adopted in Burt v GovernorGeneral [1992] 3 NZLR 672 (CA). See, for example, $R v$ Secretary of State for Foreign and Commonwealth Affairs ex parte Rees-Mogg [1994] QB 552 (Divisional Court).

199 Mercury Energy, above n 72.

200 Ibid, at 391. Elsewhere I have wondered if this threshold might be usefully described as "flagrant impropriety": see Knight "A Murky Methodology", above n 9, at 203. 
As noted earlier, this approach has been deployed in a number of other cases straddling the public-private divide. ${ }^{201}$ The Court of Appeal reiterated the applicability of this approach to procurement decisions in the Lab Tests case. ${ }^{202}$ The Court ruled that the commercial context dictated a limited approach to review of a District Health Board's procurement decision. Review was unlikely unless there was bad faith, corruption or fraud — or "analogous situations" - even where there were allegations of conflicts of interest and questions about the proper process to be followed. ${ }^{203} \mathrm{~A}$ similar approach is evident in the Air New Zealand $v$ Wellington International Airport case in a challenge to the landing charges set by the airport company, albeit subject to a lengthy dissent from Baragwanath J. ${ }^{204}$ This limited justiciability has also been hinted at in the review of decisions of (legislatively mandated) adjudicators under the Construction Contracts Act 2002, even to the extent that it may preclude the courts from remedying some legal errors in interpreting contracts. ${ }^{205}$

Outside the commercial sphere, this methodology can also be seen. The Court of Appeal ruled in the Boscawen v Attorney-General case that the Attorney-General's reporting function under s 7 of the New Zealand Bill of Rights Act 1990 was non-justiciable, essentially on constitutional grounds. ${ }^{206}$ In doing so, the Court perhaps left the door open for review in the hypothetical situation of a bad faith refusal to undertake the function. ${ }^{207}$ It has also been adopted in cases reviewing prosecutorial discretion. ${ }^{208}$

The restriction of the available grounds of review in the name of nonjusticiability has some analogy with the preceding category. Particular contexts and circumstances led to the deployment of a narrow range of grounds of review, resulting in greater latitude for the decision-maker.

201 For an excellent analysis of this group of decisions, see Wilberg, above n 60 .

202 Lab Tests, above $\mathrm{n} 76$.

203 Ibid, at [91].

204 Air New Zealand Ltd v Wellington International Airport Ltd, above n 71, at [103]. See discussion at 71 above. Compare also Air New Zealand Ltd $v$ Nelson Airport Ltd HC Nelson CIV-2007-442-584, 16 June 2008 and Air New Zealand Ltd v Nelson Airport Ltd HC Nelson CIV-2007-442-584, 27 November 2008.

205 Willis Trust Co Ltd v Green HC Auckland CIV-2006-404-809, 25 May 2006; Tayler v LaHatte HC Auckland CIV-2007-404-6843, 24 Jun 2008; John Ren "Judicial Review of Construction Contract Adjudicators" [2005] NZLJ 461.

206 Boscawen v Attorney-General [2009] NZCA 12, [2009] 2 NZLR 229 at [36].

207 Ibid, at [40]-[41].

208 Polynesian Spa Ltd v Osborne [2005] NZAR 408 (HC). The courts also have the co-extensive power to intervene and stay criminal proceedings if they amount to an "abuse of process", an approach which mimics the threshold for intervention in review cases: see Fox v Attorney-General [2002] 3 NZLR 62 (CA). 


\section{Variable intensity in the domain of human rights}

Beyond the domain of public wrongs, variable intensity is also evident in the methodology of human rights review. Much has been written on the variability of the proportionality calculus used to evaluate justified limitations on rights, ${ }^{209}$ including by Professor Taggart himself. ${ }^{210}$ Some members of our Supreme Court have also come to acknowledge the role of deference or margins of latitude or appreciation in this calculus. ${ }^{211}$

Perhaps, though, there also exist other opportunities for variable intensity of review within this human rights framework. It has been assumed by many that compliance with the New Zealand Bill of Rights Act 1990 must be absolute. That is, a public body or official must have properly applied the Bill of Rights Act (in a holistic sense, including the operative provisions which may excuse prima facie breach of rights) in the eyes of the court. ${ }^{212}$ The human rights field is where intensive review has reigned without much dissent. The differently calibrated intensities of review have led to the present bifurcation which Professor Taggart laments but ultimately accepts. Looking at the relationship in a different way, though, it is possible to locate the Bill of Rights Act jurisprudence within the orthodox categorical approach. Noncompliance with the Bill of Rights Act is simply an error of law on the part of the public body or official. Although this connection is rarely explained, it fits with the (strict) methodologies deployed in the Bill of Rights Act field and traditional "lawfulness" or "illegality" grounds.

Again, though, this is a categorisation which is not immutable and may not always be appropriate. In the early days of the Bill of Rights Act, and following the Canadian approach, New Zealand adopted the structured and strict $R v$ Oakes methodology for assessing the justifiability of limitations

209 For an eclectic collection see: Julian Rivers "Proportionality and Variable Intensity of Review" (2006) 65 CLJ 174; Hickman, above n 109; Thomas Poole "Between the Devil and the Deep Blue Sea: Administrative Law in an Age of Rights" in Linda Pearson, Carol Harlow and Michael Taggart (eds) Administrative Law in a Changing State: Essays in Honour of Mark Aronson (Hart Publishing, Oxford, 2008) 15; and Janet McLean "The Impact of the Bill of Rights on Administrative Law Revisited: Rights, Utility, and Administration" [2008] NZ L Rev 377. See generally Evelyn Ellis (ed) The Principle of Proportionality in the Laws of Europe (Hart Publishing, Oxford, 1999).

210 Taggart "Proportionality", above n 2, at 449.

211 See, for example, Tipping $\mathrm{J}$ in $R v$ Hansen, above $\mathrm{n} 19$, at [119]. See also $R$ (Begum) $v$ Governors of Denbigh High School [2006] UKHL 15, [2007] 1 AC 100 [Denbigh] and $R$ (ProLife Alliance) v British Broadcasting Corp [2003] UKHL 23, [2004] 1 AC 185.

212 See Joseph, above n 8, at 878-880; Taylor, above n 85, at [16.16], [16.18]-[16.19]. See also Paul Rishworth and others The New Zealand Bill of Rights (Oxford University Press, Melbourne, 2003) at 191; and Andrew Butler and Petra Butler The New Zealand Bill of Rights Act: A Commentary (LexisNexis, Wellington, 2005) at [31.5.2]. 
under s $5 .{ }^{213}$ As mentioned, nowadays there is greater acknowledgement of the role of deference within that proportionality methodology. ${ }^{214}$ However, some judges in Canada have recently begun to query the automatic deployment of an Oakes-style analysis when reviewing the suitability of limitations on rights. For example, in his dissent in Multani $v$ Commission scolaire Marguerite-Bourgeoys, LeBel J questioned the monolithic position the Oakes analysis had assumed in all human rights cases and pondered whether ordinary (and more relaxed) administrative law principles should be more prevalent in some cases. ${ }^{215}$

Similar questioning of the strict approach to the resolution of Bill of Rights questions can also be seen locally. In the recent Morse $v R$ case, William Young P was "distinctly unenthusiastic" about treating the question whether a protester's behaviour was "disorderly" as a mixed question of law and fact. ${ }^{216}$ In his separate reasons, in agreement with Arnold J that the protester's appeal on a question of law should be declined, he doubted that every criminal case engaging human rights "must be resolved by an evaluative exercise which is legal in character and thus capable of being relitigated through the appeal system". ${ }^{217}$ As the judges below had correctly stated the test for disorderly behaviour, William Young J considered the factual evaluation - which essentially involved the application of the proportionality calculus or "balancing test" 218 under s 5 - could only be impugned if the fact-findings were not reasonably open. ${ }^{219}$

These recent sentiments seem to revive the difficult debate about whether the critical s 5 calculus is a legal question or a merits question, ${ }^{220}$ as well as adding more fuel to the contemporary debate about the role of deference or variability in rights-review. In the field of human rights, the variability of proportionality is increasingly acknowledged. There are also hints of

213 Ministry of Transport $v$ Noort [1992] 3 NZLR 260 (CA) at 283-284, effectively adopting Dickson CJ's test from $R v$ Oakes [1986] 1 SCR 103.

214 See above $\mathrm{n} 22$.

215 Multani v Commission scolaire Marguerite-Bourgeoys [2006] 1 SCR 256.

216 Morse v R [2009] NZCA 623, [2010] 2 NZLR 625 at [46]. Arnold J expressed no view on the point, implicitly assuming that there was no impediment to looking at matters afresh on appeal. Glazebrook J accepted the issue was "either a question of fact or possibly a mixed question of fact and law" but considered both such questions could be addressed in a second appeal: ibid, at [111]-[112].

217 Ibid, at [46]. Compare Denbigh, above n 211; Belfast City Council v Miss Behavin' Ltd [2007] UKHL 19, [2007] 1 WLR 1420; and Gaunt v Ofcom [2010] EWHC 1756 (Admin).

218 Morse $v$ R, above $\mathrm{n} 216$, at [111] (per Glazebrook J).

219 Ibid, at [49] and [50].

220 For a useful discussion, see Rishworth and others, above n 212, at 190-194. 
alternative methodologies that could see a more restrained approach being adopted to the supervision of Bill of Rights questions, if they gain greater currency.

\section{E Conclusion}

Resort to a wider conception of variable intensity enlarges the corpus of cases adopting variable intensity of review. Understanding variable intensity as reflecting compromises between the countervailing principles of vigilance and restraint opens up the view to include a number of other judicial techniques which contemplate the contextualism-variability paradigm. Many of these techniques involve the overt application of variable intensity of review. Some techniques are relatively mainstream and unlikely to prompt concern. Other techniques that are being toyed with by some members of the judiciary are likely to be more controversial. Regardless, this corpus of cases is further evidence of the variability of intensity in New Zealand's judicial review.

\section{Conclusion: Acknowledging (and Calibrating) Variable Intensity}

An examination of variable intensity of review in New Zealand suggests a quite vexed position. Increasingly, there is open acceptance of an overt form of variable intensity amongst the judiciary, although senior judges who are responsible for overseeing the development of law remain sceptical. While the rudimentary idea of a sliding scale or more intense form of unreasonableness review has proved popular amongst the High Court, some other judges seem uncomfortable with aspects of an explicit process of calibration of intensity. And, of course, the language of the methodology has proved to be contentious. In contrast, academics and those from the profession have been much more willing to recognise the existence of variable intensity of review.

The commitment to contextualism is strong, partly founded on the simplicity project championed by Lord Cooke. But the courts remain reticent to translate this contextualism into an explicit adoption of variable intensity or deference. This is a contradictory, not a principled, position. As Professor Taggart recorded, you cannot have one without the other.

A deeper examination, however, suggests variable intensity of review is more deeply embedded in the supervisory jurisdiction, and covert variable intensity is rife in judicial methodology in New Zealand. If variable intensity of review is explained in terms of different balances reached between the countervailing principles of vigilance and restraint, various other judicial 
techniques exhibit the characteristics of variable intensity of review. That should be no surprise, given the courts' allegiance to contextualism.

This attempt to appraise the position of variable intensity of review in New Zealand was focused on capturing variability in its broadest sense. It did not distinguish between the method adopted to determine the degree of intensity applied or its critical drivers or triggers. As I stipulated at the outset, the consideration of the best mechanism to calibrate intensity remains at large and requires a broader assessment. ${ }^{221}$

Before concluding, however, it is useful to draw out some possibilities from within the New Zealand experience. ${ }^{222}$ In general terms, five different approaches are suggested. First, the categorical or doctrinal grounds of review could be endorsed, much as Professor Taggart favoured for the domain of public wrongs. Other than identifying the applicability of the ground to the circumstances and addressing overlapping grounds, there is little overt scope for variability - as the existing grounds capture an implicit calibration. This approach arguably sits comfortably with Professor Taggart's bifurcated world, where brighter lines and doctrines prescribing degrees of intensity dominate.

Secondly, the categorical grounds of review could be endorsed as a starting point, but the grounds could be enlarged or contracted in particular circumstances. This would capture the development of alternative grounds like simple unreasonableness, hard look or substantive legitimate expectation, which have a greater degree of intensity, while also recognising the deployment of limited non-justiciability in some circumstances. Although appearing somewhat ad hoc, this is not an insufferable state of affairs. The approach has two discrete stages. The first considers whether the presumption that the orthodox grounds of review apply should be rebutted in the circumstances of the particular case. The second involves application of the orthodox or alternative grounds, each with their implicit degree of intensity. In some respects, this is close to the present position in New Zealand, modelled on the ad hoc and occasional application of a more intense form of unreasonableness, along with restriction of the grounds in some particular contexts.

221 I acknowledge I may have perhaps jumped the gun in earlier proposing a schema arising out of the developments in the unreasonableness ground: Knight "A Murky Methodology", above n 9, at 201.

222 See the analogous identification of different approaches to restraint in Jeff A King "Institutional Approaches to Judicial Restraint" (2008) 28 OJLS 409. He examines different forms of "institutionalism" (an assessment based on the relative merits of the judicial process and administrative decision-making respectively), but also discusses "non-doctrinal" (case-by-case assessment) and "formalist" (objective categorical assessment) approaches. 
Thirdly, the concept of variable intensity could be embraced through the adoption of a sliding scale of intensity and a two-stage approach to the judicial method. The courts could first plot the degree of intensity on a continuum between restraint and vigilance, explaining the contextual factors leading to this calibration. They would then apply the so-defined intensity to the circumstances of the particular case.

Fourthly, and closely aligned to the third approach, a two-stage approach could similarly be adopted. However, rather than a continuum with infinite possible degrees of intensities, a number of more discrete standards of review could be adopted, as was the practice for many years in Canada.

Finally, the implicit constraints of the grounds of review and any attempt to explicitly calibrate intensity could be shed altogether. A simpler and more discretionary standard for intervention could be adopted, as was deployed in $R v$ Panel on Take-overs and Mergers, ex parte Guinness plc ${ }^{223}$ and in Electoral Commission v Cameron, ${ }^{224}$ and was contemplated by Tipping $\mathrm{J}$ in argument in the $\mathrm{Ye}$ case. Judicial intervention would be based on a one-stage assessment, whether the judges considered something had gone sufficiently wrong to justify intervention.

As will be evident, each of these possibilities has different benefits, but none are entirely trouble-free. I resist rehearsing the benefits and drawbacks here, because that is a much larger project, beyond the scope of this article. But an analysis and evaluation of these different methodologies for calibrating intensity, undertaken with an acceptance that variable intensity is not heretical, is needed if we are to progress beyond the present muddle. Indeed, that is no more than to repeat the plea Mike made in his ultimate article in this area: ${ }^{225}$

We must get beyond simply talking about context and actually contextualize in a way that can generate generalizable conclusions. In short, we need a map of the rainbow of review that is reliable and helpful, and we need willing cartographers.

223 Guinness, above n 53.

224 Electoral Commission v Cameron [1997] 2 NZLR 421 (CA).

225 Taggart "Proportionality", above n 2, at 454. 